ing from the other in sharply-defined characters, which, being products of the germ-plasm, are transmissible, though they may be eliminated by selection. He contrasts this view, which is not according to the Darwinian tradition as commonly accepted, with his own-which is entirely "Darwinian "-based on osteological characters according to which the evolution of species is quite otherwise, demonstrating a condition of continuous development to be traced by means of, say, a horn or the cusp of a tooth; or, in other words, on "characters which happen to be so conspicuous as to attract the eye of the zoologist."

Having disposed of the Darwinian "tradition," he proceeds to point out a more excellent way of interpreting the mazes of evolution, and this by means of a "newly-discovered law of multiple-evolution" derived from the discoveries of palæontology, which "proves" that "every organism is made up of an almost infinite number of characters, each of which is in a continuous state of movement, either originative, progressive, or retrogressive." But this idea of "multiple-character evolution" cannot fairly be said to be new. Further, if Prof. Osborn has independently arrived at this conception of evolution, he has done so through his own wide knowledge of living animals, and not entirely, as he seems to believe, through his brilliant discoveries in palæontology. Palæontology, in short, cannot be said to "prove" that every organism is made up of an infinite number of characters ..." for palæontology can "prove" no more than can be attested by such skeletal and dermal structures as are capable of fossilisation. The characters furnished by musculature, viscera, "behaviour," and the "emotions," for example, are all factors of evolution which can only be imperfectly inferred, not demonstrated, by the palæontologist.

In stating that Prof. Osborn could find " no evidence whatever in support of the theory that species may arise from fortuitous, saltatory characters," the reviewer felt that he was accurately interpreting Prof Osborn's assurance that he did not "know of a single instance where the field observer in mammalogy or palæontology has recorded a new saltatorial character which is known to be of any significance to the race." Prof. Osborn's reference to teratological cases does not seem to help him.

The reviewer frankly admits that he was wrong in suggesting that Prof. Osborn was to be regarded as in sympathy with the theory of evolution by loss of characters.

The Reviewer.

\section{Simple Device for Controlling the Movements of Paramccia.}

EVERYONE who is concerned in the teaching of elementary zoology knows the great difficulty of so controlling the movements of Paramcecium that students can distinguish the essential features of its structure. Of all the methods adopted for this purpose of which I have hitherto heard, none has ever given me such successful results as one which I tried recently in this department as an experiment, and the advantages of which combine simplicity with very great control over the animals.

A small quantity of ordinary gum is painted on a glass slide, and allowed to become nearly dry; a drop of water containing the Paramcecia is then placed on the gum and covered in the ordinary way with a cover-glass. At first the gum will scarcely interfere with the movements of the animals at all, but within a few minutes, as the gum diffuses through the water, they will be seen to move more and more slowly, and ultimately they will be unable to move at all. Finally, the irritation caused by the gum will result in the discharge of the trichocysts.
This method of using the gum enables the student to observe the Paramœecia at first in an almost normal condition, and afterwards to make a careful and detailed examination of them at his leisure. The normal shape and appearance are retained for a long time, even when the animal has become stationary, save that the gullet tends gradually to disappear, possibly through clogging with the gum.

R. W. HaROLd Row.

Zoological Department, King's College (University of London), November 8.

\section{MONUMENTS AND LIGHTNING.}

THE liability of monuments to be struck by lightning is the subject of a recent memoir in the Atti della Pontificia Accademia dei Nuovi Lincei by Prof. Ignazio Galli. The occasion of this note was the destruction at Santamaria di Capua Vetere, in the province of Caserta, in October, I9I4, of a fine monument erected in I895 in memory of the battle fought near to Volturno in 1860. This monument of travertine marble, about 95 feet high, consisted of a stately column on a substantial pedestal, surmounted by a colossal bronze statue of Victory about ro feet high, weighing I 500 pounds. This statue was fixed in the summit of the column by an iron rod which penetrated about half-way down the column. The monument stood in the quadrangle of the communal building, far from any high trees. During a violent thunderstorm about 2 a.m. a lightning stroke threw down the great bronze statue, and destroyed the upper half of the column. It is thought that the destruction might have been averted had an efficient metallic conductor connected the bottom of the iron rod to a damp stratum of soil. It is evident that an insulating mass of marble, many feet high, between a metal object and the earth affords no protection whatever against a severe thunder-stroke.

Prof. Galli takes occasion to refer to similar catastrophes which befell a column at Constantinople in the year 548, and another dedicated to Constantine the Great in the same city in the year IIOI. In Rome in the fourteenth century the column of Marcus Aurelius Antoninus was badly damaged at the top; and in the same century the statue of Trajan on the summit of the celebrated column of Trajan was likewise destroyed. Tacitus records how in the year 6r A.D. the Baths of Nero, erected scarcely one year before, were destroyed by lightning. More recent times have witnessed the destruction of the tower of the Castello of Milan (152I), that of Ivrea ( 1676$)$, of San Nazaro at Brescia ( 1769 ), and of the fortress of the Lido at Venice (1808). In 1572 the flagstaff of the Castle of St. Angelo in Rome was destroyed, with the bronze statue of the Archangel Michael. Between the years I 606 and I 809 the basilica of St. Peter's was struck, generally on the cross or the golden ball, at least twenty-two times. On the last occasion (r809) the Pope, Pius VII., had already begun preparations for fixing lightning conductors. For more than a whole century these conductors have effectually preserved the structure from damage. 